\title{
Identifying and Measuring Multilevel Influences on College-Aged Athletes' Multiple Health Behavior: A Pilot Study
}

\author{
Karly S. Geller*, Madeline A. Herbert \\ Department of Kinesiology \& Health, Miami University, Oxford, USA \\ Email: "gellerks@miamioh.edu
}

Received 24 December 2013; revised 30 January 2014; accepted 5 February 2014

Copyright (C 2014 by authors and Scientific Research Publishing Inc.

This work is licensed under the Creative Commons Attribution International License (CC BY).

http://creativecommons.org/licenses/by/4.0/

\section{(c) (i) Open Access}

\section{Abstract}

The current study gathered preliminary data relative to the influences on intercollegiate athletes' multiple health behavior. A secondary objective was to inform future measurement of identified factors. A sample of 20 intercollegiate athletes participated in an open-ended survey, followed by a corresponding focus groups ( $\approx 90$-minute). Qualitative data were gathered relative to the factors impacting athletes' excessive alcohol intake, fruit and vegetable consumption (FVC), and maintenance of physical activity after college. In general, participating athletes reported influences within their social and physical environments (friends, bar accessibility, etc.) as the leading enablers of their excessive alcohol intake, while individual level influences were the most salient reasons not to drink excessively (responsibilities, health, etc.). Individual characteristics (taste preference, health, and expense) and the physical environment (availability and accessibility) were reported as the most salient levels of influence on athletes' FVC. And when anticipating future maintenance of physical activity, athletes mostly reported individual level influences (outcome expectation, intrinsic motivation, etc.), with mention of family and friend influences. An in-depth comparison of current outcomes to similar research among young adult and athlete populations is provided, including validated measurement scales and future research suggestions. Current results provide an essential foundation for progressive research examinations among similar populations.

\section{Keywords}

Student Athletes; Physical Activity Maintenance; Alcohol; Nutrition; Multiple Health Behavior

\footnotetext{
${ }^{*}$ Corresponding author.
} 


\section{Introduction}

There is a strong evidence to suggest clustering among common health and health-risk behaviors, characterizing the lifestyle of most US adults [1]-[3]. Unfortunately, the majority of American adults meet the criteria for 2 or more health-risk behaviors [2]. When risky health behaviors co-occur, the negative health-related outcomes multiply [1] [4], and health-care and disability costs increase dramatically [5] [6]. On the other hand, healthy behaviors also co-occur, and intervention research reports the natural adoption of untargeted healthy behaviors following the promotion of a similar behavior [7]-[9]. Given the potential of healthy lifestyle promotion, multiple health behavior (MHB) change is becoming a large focus among health promotion researchers. Specifically, MHB interventions are estimated to reduce chronic disease by approximately $70 \%$ [10], as well as significantly improve quality of life [11].

Despite dissimilar environments, the health-related risks experienced by college-aged athletes are similar to their nonathlete counterparts. Negative changes to diet, physical activity, and alcohol intake increase across adult development [12] [13]. And similar to most US adults, college-aged athletes with one health-risk behavior are at an increased risk for multiple health-risk behaviors [14]. As graduating student athletes become members of the normal adult population, they significantly contribute to the overall health of the US population [15]. The factors contributing to college-aged athletes' MHB may be distinct from factors impacting nonathletes, requiring preliminary understanding.

Although minimal, examinations of nutrition quality among college-aged athletes consistently report most do not meet the dietary guidelines recommended for adult athletes [16] [17]. Furthermore, college athletes appear to be at higher risk for excessive alcohol consumption compared to nonathlete populations [18] [19]. Relative to physical activity, evidence among former athletes concedes that, unless activity is continued, the health benefits of prior athletic participation are not maintained [20]-[24]. However, limited to no research has investigated the influences on athletes' physical activity maintenance following the end of their sport career.

\subsection{Measuring Athletes' Multiple Health Behavior (MHB)}

The multiple health risks reported among college athletes is a public health concern, requiring further understanding of the factors motivating their excessive alcohol intake, FVC, and physical activity maintenance. However, effective MHB research relies on common measurement and assessment protocol across behaviors and health promotion constructs [25]. In an effort to inform progressive future research, common assessments of alcohol intake, FVC, and physical activity are summarized in the following sections.

In absence of clinical trials relative to the potential benefits of daily alcohol intake, no national recommendations currently exist. A recent systematic review and meta-analysis reported light to moderate daily alcohol consumption ( $\leq 1$ to 1 - 2 drinks per day) as protective against multiple cardiovascular outcomes [26]. However, the line between health benefit and health risk remains ambiguous due to unclear relations between alcohol dose-response and certain health outcomes [27].

Without evidence-based guidelines, the assessment of alcohol intake is far from standardized. The American College Health Association-National College Health Assessment (NCHA) is a national research survey that collects information about students' health habits, behaviors, and perceptions, including alcohol intake [28]. Common measures of alcohol abuse among young adults have been adapted from the Harvard School of Public Health College Alcohol Study (CAS) [29] and the Rutgers Health and Human Development Project [30]; specifically assessing heavy episodic drinking or binge drinking across various time periods. The Daily Drinking Questionnaire (DDQ) [31] is another widespread assessment, and has been used to assess alcohol consumption among college students [32] [33] More specifically, blood alcohol concentration (BAC) has been estimated among college athletes with 4 brief questions, asking athletes to self-report their gender, body weight, drinks consumed during their most recent drinking occasion, and hours between the first and last drink of this most recent occasion [34]. Future, novel assessments of alcohol consumption may find guidance in previously reported alcohol content by beverage type and amount [35].

Unlike alcohol consumption, national recommendations have been developed for both FVC and physical activity. Given various developmental categories and changing nutritional needs, the US Department of Health and Human Services (USDHHS) and US Department of Agriculture (USDA) offer recommendations for daily FVC that vary based on age, gender, and activity level [36]. Assuming college-aged athletes are commonly 17 to 23 years old and highly active ( $\geq 60$ minutes of daily physical activity), consumption recommendations include 2 to 
2.5 cups of fruit ( 4 to 5 servings) and 3 and 4 cups of vegetables (6 to 8 servings). To parallel recommendations, the National Cancer Institute (NCI) Fruit and Vegetable Screener (FVS) is a 19-item instrument gathering the usual intake frequency of fruit and vegetables in the past month [37]; which are quantified as servings based on the Food Guide Pyramid [38]. Self-reported frequency and proportion sizes can then be used to estimate FVC in Pyramid servings [39]. A more brief approach is the use of single questions for both fruit intake and vegetable intake, asking participants to report their intake in servings that directly relate to national guidelines [40].

National guidelines released by the USDHHS recommend adults engage in at least 150 minutes of moderate PA (or 75 minutes of vigorous PA) each week [41]. Two popular assessments of physical activity are the Godin Leisure-Time Exercise questionnaire (GLTEQ) [42]-[44] and the International Physical Activity Questionnaire (IPAQ) [45] [46]. Both assess three levels of physical activity (i.e., mild/walking, moderate, and strenuous/vigorous), which can be summed relative to national guidelines and/or weighted by the associated metabolic equivalent (MET) value.

\subsection{Study Purpose}

Although college athletes are at-risk for the same health behaviors as their non-athlete counterparts, the underlying mechanisms motivating athletes' adoption of certain lifestyle behaviors are likely unique. The primary research objective was to gather a preliminary understanding of the multilevel influences motivating college athletes' MHB; specifically, athletes' excessive alcohol intake, FVC, and physical activity maintenance following the end of their sport career. Results provide initial insight into the future assessment of emerging behavioral determinants, with hopes of informing progressive examinations and intervention research targeting college-aged athletes' healthy lifestyle adoption and maintenance.

\section{Methodology}

Informed consent preceded all study procedures, which were approved by the University Institutional Review Board. College student intercollegiate athletes were recruited via flyers, emails, and coach-faculty partnerships (i.e., team and classroom recruitment). After signing consent forms, athletes were asked to complete a pencil/ paper survey and participate in a corresponding focus group discussion $(\approx 90$ minutes). Participating athletes were ensured their participation was voluntary and confidential, and received an unconditional monetary compensation (\$25) for their participation. Data were collected in September/October of 2012.

\subsection{Procedures}

Participating athletes were first given 15 to 20 minutes to complete a series of open-ended questions relevant to the most salient influences on their multiple health behaviors. Guided by the holistic framework of the Social Ecological Model (SEM) [47], athletes were asked to report the influences on their health behaviors relevant to themselves and within their surrounding social and physical environments. Participants reported the barriers and enablers to their current alcohol intake and FVC, as well as the anticipated influences on their maintenance of physical activity following the end of their formal sport career. Once surveys were completed, participants participated in a corresponding focus group.

During the 90-minute focus group, the lead author led participating athletes through each survey question. Participants were encouraged to expand on and/or adjust their initial written response(s). This two-step assessment ensured clarity of all survey questions and allowed athletes to elaborate on the meaning and reasoning of their answers. The focus group was digitally recorded, and a research assistant took handwritten notes. The moderator's guide included 10 questions with relevant probe questions. The general topics included athletes' perceived barriers/enablers to excessive alcohol consumption, daily FVC, and future maintenance of physical activity. The digital recording and written responses were transcribed and conceptualized into underlying themes.

\subsection{Qualitative Thematic Analysis}

Thematic analysis was used to identify common themes and patterns within the data. Transcripts were hand coded by three members of the research team. Each coder individually conducted an in-depth review of the transcripts, and categorized athlete responses based on the multiple levels of behavioral influence outlined by 
the SEM [47]; including influences specific to the individual, social environment, and physical environment (i.e., level of influence). Inter-coder reliability was calculated as percent agreement and exceeded 0.95. Subsequently, coders met as a panel to more specifically categorize common athlete responses within each level of influence (i.e., specific influence). Agreement across coders was required prior to finalizing each category.

\section{Results}

Participants were 20 undergraduate students participating on an intercollegiate athletic team. The sample was 85\% female, ranging in age from 18 to 21 years. Participating athletes represented both individual (80\%) and team sports (20\%); specifically, including dance (45\%), gymnastics (35\%), water polo (15\%), and volleyball (5\%).

Table 1 reports participating athletes' relative responses by grouped enabler/barrier to their excessive alcohol intake. The most salient influences on athletes' excessive alcohol intake were friends, socializing and celebrations.

Table 2 reports athlete quotes relevant to the influence on their FVC. The most frequently emerging influences on participating athletes' FVC were availability/accessibility and preference.

Table 3 provides athlete responses when asked about their future physical activity maintenance. Athletes most often reported outcome expectancies and intrinsic motivation when asked to anticipate their future physical activity maintenance (i.e., following the end of their sport career).

\section{Discussion}

The current study examined the most relevant influences on college-aged athletes' MHB. In general, the social and physical environments surrounding athletes largely contributed to their excessive alcohol intake; which supports previous examinations among college-aged non-athletes [48]-[51] and athletes [52]-[55]. Similar to the general US population, preference and availability/accessibility were the most commonly reported influence on participating athletes' FVC [56] [57]. Regarding their future physical activity maintenance, athletes' anticipated strong outcome expectancies and intrinsic motivation; with no comparative research to report. The following paragraphs suggest measurement scales relevant to the influences that emerged.

\subsection{Excessive Alcohol Consumption}

Current outcomes highlight the importance of measuring and examining factors related to alcohol availability/

Table 1. Participating athletes’ self-reported influences on their excessive alcohol consumption.

$$
\text { Athlete Perceived Enablers-Quotations }
$$

Construct

"Depends on what group of friends I drink with"; "Whether or not my friends are drinking"; "Sorority socials offer more opportunities to drink"; "Fun way to spend the weekends"; "If I'm going to a party I'll drink”; "It’s a social gathering \& enjoyable being with friends”.

“Celebrating a good performance”.

“Bars are very easy to go to \& get into”; "Parties are often being thrown”.

“College in general is a big influence”; “I’m young \& don’t have many responsibilities”.

Athlete Perceived Barriers-Quotations

Friends/Socializing

"I’m a leader, \& I want to make good decisions"; “Team sobriety oath”; "Not if I have to be productive the following day"; "Not during the week because of classes \& practice”; "Leads to bad decisions frequently".

"Not if I have to pay for it".

Celebrations

“I don't like the way most of it taste”; “I don’t like feeling out of control”.

Availability/Accessibility

College Environment

Construct

Character/Responsibility

Expense

Preference

"I want to stay healthy"; "Stay healthy \& at my best”; "bad effects on my body"; "effects of alcohol my body \& how it affects decision-making \& motor skills"; "it is kind of weird to go to parties \& not drink, but I know I'll feel better when I don't”.

Health 
Table 2. Participating athletes’ self-reported influences on their fruit and vegetable consumption.

\begin{tabular}{|c|c|}
\hline Athlete perceived enablers-quotations & Construct \\
\hline $\begin{array}{l}\text { "I really like eating fruits \& vegetables because they taste good”; "Delicious”; “I like them”; Taste good”; } \\
\text { "I love fruits \& vegetables"; “fruit \& vegetables are delicious". }\end{array}$ & Preference \\
\hline $\begin{array}{l}\text { "Help maintain a healthier diet”; "Make me feel energized \& good about myself”; "Help maintain a } \\
\text { healthier diet”; "I feel bad if I don’t get the usual amount I eat normally”; "I feel better after eating them } \\
\text { rather than eating unhealthy foods"; "intrinsic-they make me perform better, faster stronger”; I like how } \\
\text { they make me feel \& give me energy. I also know they are good for me \& will help my future”; "I know } \\
\text { they are healthy so I feel good when I eat them”; "to stay healthy so I can live a long healthy life”. }\end{array}$ & Health/Diet \\
\hline $\begin{array}{l}\text { "How easy is it to make them or fit them into meals"; "Taking fruit on the go from dining Hall”; "I love } \\
\text { fruits \& vegetables so as long as I can get them I will”; "The main reason would be whether or not I can } \\
\text { get a hold of the fruits or vegetables". }\end{array}$ & Availability/Accessibility \\
\hline Athlete Perceived Barriers-Quotations & Construct \\
\hline $\begin{array}{l}\text { "Eating healthier is usually more expensive”; “If it’s really expensive I’ll eat less”; “more expensive than } \\
\text { any unhealthy foods”. }\end{array}$ & Expense \\
\hline
\end{tabular}

Table 3. Participating athletes’ expected influences on their future physical activity maintenance.

$$
\text { Athlete perceived enablers }
$$

"I am a bodybuilder so my career will never be over I just like the healthy lifestyle"; "I am happier when I am in good physical shape"; "I will want to maintain a happy lifestyle"; "Keeps health issues under control"; "Knowing the benefits of staying in shape \& what happens if you're not"; " I like the feeling of being healthy"; "Wanting to stay fit \& feel good about myself”; "Physical activity will keep me in shape \& keep diseases away"; "Remaining healthy \& in shape so I can live a longer \& lead a healthier lifestyle"; "How healthy I feel inside \& about myself".

"I want to stay active so I can remain healthy as an adult \& live a longer \& healthy lifestyle as I age. I also want to keep a healthy appearance"; "I want to look good"; "I like to feel \& look good"; "Definitely how I will look physically".

"It is internal \& I will probably try to do workout classes, but I will definitely try to maintain physical fitness by group classes”.

"Knowing the example I set for others”; "Setting an example being respected”; “friends/family”.

Outcome Expectations: Health \& Fitness

Outcome Expectations: Physical Appearance

Intrinsic Motivation

Social Influences

"What am I studying in grad school will help me keep in mind the benefits of exercise"; "My major's health promotion so I want to lead by example \& be physically fit. I also want to live a long healthy life \& I know exercise will help me”.

"Working out is how I relieve stress or get my mind off of certain things. I am sure I will still have the stress once I'm out of college \& so will still exercise"; "Being active is a lifestyle for me. I am anxious \& moody when I don’t work out. I have to in order to feel good about myself”; "I want to feel good about myself which physical activity allows me to do"; "Mental, physical, \& spiritual benefits of physical activity".

accessibility within athletes' social and physical environments, supporting theory and previous evidence. High social and physical availability/accessibility fosters alcohol consumption, becoming a strong social norm [49]. Participating athletes frequently reported availability within the physical environment as a strong, positive influence on their excessive alcohol consumption. Similarly, Weitzman and colleagues [58] reported significant associations between alcohol outlet density and college students' heavy drinking, frequent drinking, and drinking-related problems.

The College Athlete Alcohol Survey is a holistic assessment of the multilevel factors influencing college athletes' alcohol intake (organizational, community, interpersonal, and intrapersonal) [59]. Examinations of sociallevel motivations to consume alcohol have customarily targeted young adults' perceived social norms and role modeling experiences. The Drinking Norms Rating Form (DNRF) assesses alcohol-related social norms by asking participants to estimate their friends' alcohol consumption [60], demonstrating utility among both non-athlete [61] [62] and athlete populations [63] [64]. Athletes have also been asked to estimate the alcohol consumption of more specific reference groups, including their closest athlete friend, the typical college athlete, their closest non-athlete friend, and the typical non-athlete student [65].

Individual intent or motive is also influenced strongly by the social environment, and commonly examined in 
relation to excessive alcohol consumption. Relative assessments of athletes' motives to consume alcohol include the Drinking Motive Measure (DMM) or Drinking Motives Questionnaire Revised (DMQ-R) [66] [67], assessing 4 subscales (social, enhancement, coping, and conformity). Similarly, Abbey et al. [49] captured perceived social norms relative to alcohol intake (perceived obligation, drinking to be social, and availability of alcohol in social settings) and network members' modeling of alcohol consumption (i.e., how frequently one's spouse/dating partner, friends, and family members consumed alcohol) with high reliability. More recently Martens and colleagues [68] developed and validated the Athlete Drinking Scale (ADS) to directly capture athletes' motivations for alcohol consumption. The ADS assesses sport-related reasons for alcohol consumption, including athletes' perceived positive reinforcement, team/group influence, and sport-related coping.

In addition to the social impact, availability/accessibility of alcohol within the physical environment has been assessed objectively and subjectively. Recent objective measures of alcohol availability have used participants' home addresses to determine the level of neighborhood exposure [69] and proximity to venues serving alcohol [70]. In comparison to objectively measured or actual alcohol availability, individuals' perceived availability has been suggested to have a domineering effect on their consumption [71]; The subjective availability of alcohol has been measured with appropriate reliability, including one's perceived convenience of obtaining alcohol, willingness to travel for alcohol, and concerns relative to the price of alcohol [49]. Similar research specifically targeting college-aged athletes is warranted.

\subsection{Fruit and Vegetable Consumption}

The availability/accessibility and preference of fruit and vegetables were the most commonly reported influences on participating athletes' consumption, which is similar to previous evidence among youth populations [56] and young adults [57]. Measurement scales to assess adults' taste preference for fruits and vegetables separately have been recently reported and validated [58]. Specific to the physical environment, research examining fruit and vegetable availability in relation to college students' FVC found higher intake among those living in residence halls, compared to college students living off campus or with their parents [72]. However, due to varying physical environments, these relationships may vary across distinct college campuses.

Similar to alcohol, the availability of fruit and vegetables within the physical environment has been measured both objectively [73] [74] and subjectively [74]-[76]. Like alcohol, fruit and vegetable availability has been objectively assessed by counting venues selling fruits \&/or vegetables via residence and venue addresses [73] [74]. Subjectively, individuals' perceived ease/difficulty of accessing fruits and vegetables have been self-reported with various Likert scales [75] [76]. Specific to college campuses, the nutritional content and purchasing sources of specific foods has been examined with detailed food/beverage inventories [77]. Relevant to student athlete dining halls, which are offered specifically to athletes on many college campuses, research has used the Athletic Dining Hall Questionnaire to capture athletes' perception of the foods provided [78]. However, such inclusive dining halls are not offered on every campus, and this is only one of many food environments college athletes are exposed to (e.g., home, neighborhood, etc.). A more holistic assessment specific to fruit and vegetable availability within the home and community environments has been reported and validated among youth populations [79]. Given the unique social and physical environments experienced, further validation among various athlete populations is warranted.

\subsection{Physical Activity Maintenance}

When anticipating influences on their physical activity maintenance after college, the majority of athletes reported outcome expectancies and intrinsic motivation. Athletes reported strong outcome expectancies relevant to health, fitness, and body image; which supports previous physical activity maintenance research among adult office workers [80] and adult women [81]. The current study is among the first to specifically target college-aged athletes' physical activity maintenance. Intrinsic motivation, or motivation derived from internal satisfaction, was consistently reported as motivating participating athletes' physical activity maintenance after their formal sport career ends. Although there is no current evidence directly comparable to college-aged athletes, previous evidence has highlighted the significance of intrinsic motivation in relation to women's regulation of physical activity [81].

One relative theoretical approach to understanding intrinsic or internal motivation as it relates to sustained regular physical activity is Deci and Ryan's Self-Determination Theory (SDT) [82]-[84]. Internal motivation is 
promoted by the achievement of one's psychological needs, including the human need for competence, autonomy, and relatedness [83]. When one's such needs are met, they experience increases in their self-esteem, selfworth, and well-being; which is hypothesized to facilitate more self-determined forms of behavioral regulation [83]. Validated assessments for each SDT construct is available from the official SDT website (http://selfdeterminationtheory.org/).

\section{Conclusion}

Certain limitations of the current research are noteworthy. The sample size was relatively small and mostly female, only representing certain intercollegiate sports and limiting generalizations. The methodology was descriptive, limiting conclusive inferences and direct study comparisons. The current research is a preliminary examination of the factors influencing college-aged athletes' MHB, and is among the first to gather prospective information about athletes' future maintenance of physical activity. Results may be informative to future assessments among similar populations. Similar investigations are suggested among additional sports, with attention to differences between team and individual focused sports.

\section{Acknowledgements}

This research was funded by the Committee on Faculty Research, Office of Advancement of Research \& Scholarship (OARS) at Miami University, Ohio.

\section{References}

[1] Berrigan, D., Dodd, K., Troiano, R.P., Krebs-Smith, S.M. and Barbash, R.B. (2003) Patterns of Health Behavior in U.S. Adults. Preventive Medicine, 36, 615-623. http://dx.doi.org/10.1016/S0091-7435(02)00067-1

[2] Fine, L.J., Philogene, G.S., Gramling, R., Coups, E.J. and Sinha, S. (2004) Prevalence of Multiple Chronic Disease Risk Factors: 2001 National Health Interview Survey. American Journal of Preventive Medicine, 27, 18-24. http://dx.doi.org/10.1016/j.amepre.2004.04.017

[3] Poortinga, W. (2007) The Prevalence and Clustering of Four Major Lifestyle Risk Factors in an English Adult Population. Preventive Medicine, 44, 124-128. http://dx.doi.org/10.1016/j.ypmed.2006.10.006

[4] Prochaska, J.J., Spring, B. and Nigg, C.R. (2008) Multiple Health Behavior Change Research: An Introduction and Overview. Preventive Medicine, 46, 181-188. http://dx.doi.org/10.1016/j.ypmed.2008.02.001

[5] Edington, D.W. (2001) Emerging Research: A View from One Research Center. American Journal of Health Promotion, 15, 341-349. http://dx.doi.org/10.4278/0890-1171-15.5.341

[6] Shinton, R. (1997) Lifelong Exposures and the Potential for Stroke Prevention: The Contribution of Cigarette Smoking, Exercise, and Body Fat. Journal of Epidemiology \& Community Health, 51, 138-143. http://dx.doi.org/10.1136/jech.51.2.138

[7] French, S.A., Hennrikus, D.J. and Jeffery, R.W. (1996) Smoking Status, Dietary Intake, and Physical Activity in a Sample of Working Adults. Journal of Health Psychology, 15, 448-454. http://dx.doi.org/10.1037/0278-6133.15.6.448

[8] Johnson, S.S., Paiva, A.L., Cummins, C.O., et al. (2008) Transtheoretical Model-Based Multiple Behavior Intervention for Weight Management: Effectiveness on a Population Basis. Preventive Medicine, 46, 238-246. http://dx.doi.org/10.1016/j.ypmed.2007.09.010

[9] Perkins, K.A., Rohay, J., Meilahn, E.N., Wing, R.R., Matthews, K.A. and Kuller, L.H. (1993) Diet, Alcohol, and Physical Activity as a Function of Smoking Status in Middle-Aged Women. Journal of Health Psychology, 12, 410 415. http://dx.doi.org/10.1037/0278-6133.12.5.410

[10] Ford, E.S., Bergmann, M.M., Kroger, J., Schienkiewitz, A., Weikert, C. and Boeing, H. (2009) Healthy Living Is the Best Revenge. Archives of Internal Medicine, 24, 1355-1362.

[11] Harrington, J., Perry, I.J., Lutomski, J., et al. (2010) Living Longer and Feeling Better: Healthy Lifestyle, Self-Rated Health, Obesity and Depression in Ireland. European Journal of Public Health, 20, 91-95. http://dx.doi.org/10.1093/eurpub/ckp102

[12] Baronowski, T., Cullen, K.W. and Basen-Enguist, K. (1997) Transition Out of High School: A Time of Increased Cancer Risk? Preventive Medicine, 6, 694-703. http://dx.doi.org/10.1006/pmed.1997.0193

[13] Cullen, K.W., Koehly, L.M., Anderson, C., et al. (1999) Gender Differences in Chronic Disease Risk Behaviors through the Transition Out of High School. American Journal of Preventive Medicine, 17, 1-8. 
http://dx.doi.org/10.1016/S0749-3797(99)00038-0

[14] Aurelia, N., Puffer, J.C. and Green, G.A. (1997) Lifestyles and Health Risks of Collegiate Athletes: A Multi-Center Study. Clinical Journal of Sport Medicine, 7, 262-272. http://dx.doi.org/10.1097/00042752-199710000-00004

[15] Friery, K.B. (2008) Incidence of Injury and Disease among Former Athletes: A Review. Journal of Exercise Physiology, 11, 26-45.

[16] Drenowatz, C., Eisenmann, J.C., Carlson, J.J., Pfeiffer, K.A. and Pivarnik, J.M. (2012) Energy Expenditure and Dietary Intake during High-Volume and Low-Volume Training Periods among Male Endurance Athletes. Applied Physiology, Nutrition, and Metabolism, 37, 199-205. http://dx.doi.org/10.1139/h11-155

[17] Rodriguez, N.R., DiMarco, N.M. and Langley, S. (2009) Position of the American Dietetic Association, Dietitians of Canada, and the American College of Sports Medicine: Nutrition and Athletic Performance. Journal of the American Dietetic Association, 109, 509-527. http://dx.doi.org/10.1016/j.jada.2009.01.005

[18] Frye, W.S., Allen, B. and Drinnon, J. (2010) Alcohol Consumption among Athletes and Non-Athletes in Christian Colleges. Journal of Research on Christian Education, 19, 313-324. http://dx.doi.org/10.1080/10656219.2010.526482

[19] Surujlal, J., Nolan, V.T. and Ubane, T. (2012) Drinking Patterns and Related Consequences among University Student-Athletes: Health and Physical Activity. African Journal for Physical Health Education, Recreation and Dance, 18, 281-292.

[20] Basilico, F. (1999) Cardiovascular Disease in Athletes. The American Journal of Sports Medicine, 27, 108-121.

[21] Dey, S., Ghosh, C., Debray, P. and Chatterjee, M. (2002) Coronary Artery Disease Risk Factors and Their Association with Physical Activity in Older Athletes. Journal of Cardiovascular Risk, 9, 383-392. http://dx.doi.org/10.1097/00043798-200212000-00013

[22] Kujala, U., Marti, P., Kaprio, J., Hernelahti, M., Tikkanen, H. and Sarna, S. (2003) Occurrence of Chronic Disease in Former Top-Level Athletes. Predominance of Benefits, Risks or Selection Effects. Sports Medicine, 33, 553-561. http://dx.doi.org/10.2165/00007256-200333080-00001

[23] Paffenbarger, S. and Lee, M. (1998) A Natural History of Athleticism, Health, and Longevity. Journal of Sports Sciences, 16, 31-46. http://dx.doi.org/10.1080/026404198366957

[24] Wyshak, G. (2003) Behavioral Practices and Mortality in Women Former College Athletes and Nonathletes. Health Care for Women International, 24, 808-821. http://dx.doi.org/10.1080/07399330390229920

[25] Nigg, C.R., Allegrante, J.P. and Ory, M. (2002) Theory-Comparison and Multiple-Behavior Research: Common Themes Advancing Health Behavior Research. Health Education Research, 17, 670-679. http://dx.doi.org/10.1093/her/17.5.670

[26] Ronksley, P.E., Brien, S.E., Turner, B.J., Mukamal, K.J. and Ghali, W.A. (2011) Association of Alcohol Consumption with Selected Cardiovascular Disease Outcomes: A Systematic Review and Meta-Analysis. British Medical Journal, 342, d671. http://www.ncbi.nlm.nih.gov/pmc/articles/PMC3043109/pdf/bmj.d671.pdf http://dx.doi.org/10.1136/bmj.d671

[27] Stockwell, T. (2013) A Reply to Roerecke \& Rehm: Continuing Questions about Alcohol and Health Benefits. Addiction, 108, 428-429. http://dx.doi.org/10.1111/j.1360-0443.2012.04076.x

[28] American College Health Association (2007) National College Health Assessment. http://www.acha-ncha.org

[29] Wechsler, H., Dowdell, G.W., Davenport, A.E. and Rimm, E.B. (1995) A Gender-Specific Measure of Binge Drinking among College Students. American Journal of Public Health, 85, 982-985. http://dx.doi.org/10.2105/AJPH.85.7.982

[30] Pandina, R.J., Labouvie, E.W. and White, H.R. (1984) Potential Contributions of the Life Span Developmental Approach to the Study of Adolescent Alcohol and Drug Use: The Rutgers Health and Human Development Project, a Working Model. Journal of Drug Issues, 14, 253-268.

[31] Collins, R.L., Parks, G.A. and Marlatt, G.A. (1985) Social Determinants of Alcohol Consumption: The Effects of Social Interaction and Model Status on the Self-Administration of Alcohol. Journal of Consulting and Clinical Psychology, 53, 189-200. http://dx.doi.org/10.1037/0022-006X.53.2.189

[32] Baer, J.S., Kivlahan, D.R., Blume, A.W., McKnight, P. and Marlatt, A. (2001) Brief Intervention for Heavy-Drinking College Students: 4-Year Follow-Up and Natural History. American Journal of Public Health, 91, 1310-1316. http://dx.doi.org/10.2105/AJPH.91.8.1310

[33] Larimer, M.E., Turner, A.P., Anderson, B.K., et al. (2001) Evaluating a Brief Alcohol Intervention with Fraternities. Journal of Studies on Alcohol, 62, 370-380.

[34] Thombs, D.L. and Hamilton, M.J. (2002) Effects of a Social Norm Feedback Campaign on the Drinking Norms and Behavior of Division I Student-Athletes. Journal of Drug Education, 32, 227-244. http://dx.doi.org/10.2190/2UYU-6X9M-RJ65-3YYH

[35] Dawson, D.A. (2003) Methodological Issues in Measuring Alcohol Use. Alcohol Research \& Health, 27, 18-29. 
[36] US Department of Health and Human Services (USDHHS) and US Department of Agriculture (USDA) (2005) Dietary Guidelines for Americans. 6th Edition, US Government Printing Office, Washington DC.

[37] Thompson, F.E., Subar, A.F., Smith, A.F., Midthune, D., Radimer, K.L., Kahle, L.L. and Kipnis, V. (2002) Fruit and Vegetable Assessment: Performance of 2 New Short Instruments and a Food Frequency Questionnaire. Journal of the American Dietetic Association, 102, 1764-1772. http://dx.doi.org/10.1016/S0002-8223(02)90379-2

[38] The Food Guide Pyramid (1992) United States Department of Agriculture (USDA), Center for Nutrition Policy and Promotion, Report No. 252, Washington DC.

[39] Greene, G.W., Resnicow, K., Thompson, F.E., Peterson, K.E., Hurley, T.G., Hebert, J.R., Toobert, D.J., Williams, G.C., Elliot, D.L., Goldman Sher, T., Domas, A., Midthune, D., Stacewicz-Sapuntzakis, M., Yaroch, A.L. and Nebeling, L. (2008) Correspondence of the NCI Fruit and Vegetable Screener to Repeat 24-H Recalls and Serum Carotenoids in Behavioral Intervention Trials. Journal of Nutrition, 138, 200S-204S.

[40] Resnicow, K., Odom, E., Wang, T., Dudley, W.N., Mitchell, D., Vaughan, R., Jackson, A. and Baranowski, T. (2000) Validation of Three Food Frequency Questionnaires and 24-Hour Recalls with Serum Carotenoid Levels in a Sample of African-American Adults. American Journal of Epidemiology, 152, 1072-1780. http://dx.doi.org/10.1093/aje/152.11.1072

[41] Physical Activity Guidelines Advisory Committee (2008) Physical Activity Guidelines Advisory Committee Report, US Department of Health and Human Services (USDHHS), Washington DC.

[42] Godin, G. and Shepherd, R. (1985) A Simple Method to Assess Exercise Behavior in the Community. Canadian Journal of Applied Sport Sciences, 10, 141-146.

[43] Godin, G. (2011) The Godin-Shephard Leisure-Time Physical Activity Questionnaire. Health and Fitness Journal of Canada, 4, 18-22.

[44] Jacbos, D., Ainsworth, B., Hartman, T. and Leon, A. (1993) A Simultaneous Evaluation of 10 Commonly Used Physical Activity Questionnaires. Medicine \& Science in Sports \& Exercise, 25, 81-91. http://dx.doi.org/10.1249/00005768-199301000-00012

[45] Craig, C.L., Marshall, A.L., Sjöström, M., Bauman, A.E., Booth, M.L., Ainsworth, B.E., Pratt, M., Ekelund, U.L.F., Yngve, A., Sallis, J.F. and Oja, P. (2003) International Physical Activity Questionnaire (IPAQ): 12-Country Reliability and Validity. Medicine \& Science in Sports \& Exercise, 35, 1381-1395. http://dx.doi.org/10.1249/01.MSS.0000078924.61453.FB

[46] Booth, M.L. (2000) Assessment of Physical Activity: An International Perspective. Research Quarterly for Exercise and Sport, 71, S114-S120.

[47] Stokols, D. (2006) Translating Social Ecological Theory into Guidelines for Community Health Promotion. American Journal of Health Promotion, 10, 282-298.

[48] Abbey, A., Scott, O., Oliansky, D., Quinn, B. and Andreski, P.M. (1990) Subjective, Social, and Physical Availability II. Their Simultaneous Effects on Alcohol Consumption. Substance Use \& Misuse, 25, 1011-1023. http://dx.doi.org/10.3109/10826089009058869

[49] Abbey, A., Scott, R.O. and Smith, M.J. (1993) Physical, Subjective, and Social Availability: Their Relationship to Alcohol Consumption in Rural and Urban Areas. Addiction, 88, 489-499. http://dx.doi.org/10.1111/j.1360-0443.1993.tb02055.x

[50] Callas, P.W., Flynn, B.S. and Worden, J.K. (2004) Potentially Modifiable Psychosocial Factors Associated with Alcohol Use during Early Adolescence. Addictive Behaviors, 29, 1503-1515. http://dx.doi.org/10.1016/j.addbeh.2004.02.028

[51] Wood, M.D., Read, J.P., Palfai, T.P. and Stevenson, J.F. (2001) Social Influence Processes and College Student Drinking: The Mediational Role of Alcohol Outcome Expectancies. Journal of Studies on Alcohol, 62, 32-43.

[52] Doumas, D.M. (2013) Alcohol-Related Consequences among Intercollegiate Student Athletes: The Role of Drinking Motives. Journal of Addictions \& Offender Counseling, 34, 51-64. http://dx.doi.org/10.1002/j.2161-1874.2013.00014.x

[53] Evans, M., Weinberg, R. and Jackson, A. (1992) Psychological Factors Related to Drug Use in College Athletes. The Sport Psychologist, 6, 24-41.

[54] Ford, J.A. (2007) Substance Used among College Athletes: A Comparison Based on Sport/Team Affiliation. Journal of American College Health, 55, 367-373. http://dx.doi.org/10.3200/JACH.55.6.367-373

[55] Wilson, G.S., Pritchard, M.E. and Schaffer, J. (2004) Athletic Status and Drinking Behavior in College Students: The Influence of Gender and Coping Styles. Journal of American College Health, 52, 269-275. http://dx.doi.org/10.3200/JACH.52.6.269-275

[56] Geller, K.S. and Dzewaltowski, D.A. (2009) Longitudinal and Cross-Sectional Influences on Youth Fruit and Vegeta- 
ble Consumption. Nutrition Reviews, 67, 65-76. http://dx.doi.org/10.1111/j.1753-4887.2008.00142.x

[57] Larson, N., Laska, M.N., Story, M. and Neumark-Sztainer, D. (2012) Predictors of Fruit and Vegetable Intake in Young Adulthood. Journal of the Academy of Nutrition and Dietetics, 112, 1216-1222. http://dx.doi.org/10.1016/j.jand.2012.03.035

[58] Weitzman, E.R., Folkman, A., Folkman, K. and Wechsler, H. (2003) The Relationship of Alcohol Outlet Density to Heavy and Frequent Drinking and Drinking-Related Problems among College Students at Eight Universities. Health \& Place, 9, 1-6. http://dx.doi.org/10.1016/S1353-8292(02)00014-X

[59] Williams, R., Perko, M., Usdan, S., Leeper, J., Belcher, D. and Leaver-Dunn, D. (2008) Influences on Alcohol Use among NCAA Athletes: Application of the Social Ecology Model. American Journal of Health Studies, 23, 151-159.

[60] Baer, J.S., Stacy, A. and Larimer, M. (1991) Biases in the Perception of Drinking Norms among College Students. Journal of Studies on Alcohol, 52, 580-586.

[61] Thombs, D.L. (1998) A Test of the Perceived Norms Model to Explain Drinking Patterns among University StudentAthletes. Journal of American College Health, 49, 75-83. http://dx.doi.org/10.1080/07448480009596287

[62] Thombs, D.L., Wolcott, B.J. and Farkash, L.G.E. (1997) Social Context, Perceived Norms and Drinking Behavior in Young People. Journal of Substance Abuse, 9, 257-267. http://dx.doi.org/10.1016/S0899-3289(97)90020-1

[63] Thombs, D.L. and Hamilton, M.J. (2002) Effects of a Social Norm Feedback Campaign on the Drinking Norms and Behavior of Division I Student-Athletes. Journal of Drug Education, 32, 227-244. http://dx.doi.org/10.2190/2UYU-6X9M-RJ65-3YYH

[64] Martens, M.P., Dams-O’Conner, K., Duffy-Paiement, C. and Gibson, J.T. (2006) Perceived Alcohol Use among Friends and Alcohol Consumption among College Athletes. Psychology of Addictive Behaviors, 20, 178-184. http://dx.doi.org/10.1037/0893-164X.20.2.178

[65] Dams-O’Conner, K., Martin, J.L. and Martens, M.P. (2007) Social Norms and Alcohol Consumption among Intercollegiate Athletes: The Role of Athlete and Nonathlete Reference Groups. Addictive Behaviors, 32, 2657-2666. http://dx.doi.org/10.1016/j.addbeh.2007.04.030

[66] Cooper, M.L. (1994) Motivations for Alcohol Use among Adolescents: Development and Validation of a Four-Factor Model. Psychological Assessment, 6, 117-128. http://dx.doi.org/10.1037/1040-3590.6.2.117

[67] Cooper, M.L., Russell, M., Skinner, J.B. and Windle, M. (1992) Development and Validation of a Three-Dimensional Measure of Drinking Motives. Psychological Assessment, 4, 123-132. http://dx.doi.org/10.1037/1040-3590.4.2.123

[68] Martens, M.P., Watson, J.C., Roylan, E.M. and Beck, N.C. (2005) Development of the Athlete Drinking Scale. Psychology of Addictive Behaviors, 19, 158-164. http://dx.doi.org/10.1037/0893-164X.19.2.158

[69] Schonlau, M., Scribner, R., Farley, T.A., Theall, K., Bluthenthal, R.N., Scott, M. and Cohen, D.A. (2008) Alcohol Outlet Density and Alcohol Consumption in Los Angeles County and Southern Louisiana. Geospatial Health, 3, 91-101.

[70] Halonen, J.I., Kivimäki, M., Virtanen, M., Pentti, J., Subramanian, S.V., Kawachi, I. and Vahtera, J. (2013) Living in Proximity of a Bar and Risky Alcohol Behaviours: A Longitudinal Study. Addiction, 108, 320-328. http://dx.doi.org/10.1111/j.1360-0443.2012.04053.x

[71] Smart, R.G. (1980) Availability and the Prevention of Alcohol-Related Problems. In: Harford, T.C., Parker, D.A. and Light, L., Eds., Normative Approaches to the Prevention of Alcohol Abuse and Alcoholism: Proceedings of a Symposium, Department of Health, Education and Welfare, Washington DC, 123-146.

[72] Adams, T.B. and Colner, W. (2008) The Association of Multiple Risk Factors with Fruit and Vegetable Intake among a Nationwide Sample of College Students. Journal of American College Health, 56, 455-461. http://dx.doi.org/10.3200/JACH.56.44.455-464

[73] Ollberding, N.J., Nigg, C.R., Geller, K.S., Horwath, C.C., Motl, R.W. and Dishman, R.K. (2012) Food Outlet Accessibility and Fruit and Vegetable Consumption. American Journal of Health Promotion, 26, 366-370. http://dx.doi.org/10.4278/ajhp.101215-ARB-401

[74] Moore, L.V., Roux, A.V.D. and Franco, M. (2012) Measuring Availability of Healthy Foods: Agreement between Directly Measured and Self-Reported Data. American Journal of Epidemiology, 175, 1037-1044. http://dx.doi.org/10.1093/aje/kwr445

[75] Gustafson, A.A., Sharkey, J., Samuel-Hodge, C.D., Jones-Smith, J., Folds, M.C., Cai, J. and Ammerman, A.S. (2011) Perceived and Objective Measures of the Food Store Environment and the Association with Weight and Diet among Low-Income Women in North Carolina. Public Health Nutrition, 14, 1032-1038. http://dx.doi.org/10.1017/S1368980011000115

[76] Caldwell, E.M., Kobayashi, M.M., DuBow, W.M. and Wytinck, S.M. (2009) Perceived Access to Fruits and Vegetables Associated with Increased Consumption. Public Health Nutrition, 12, 1743-1750. 
http://dx.doi.org/10.1017/S1368980008004308

[77] Nelson, M.C. and Story, M. (2009) Food Environments in University Dorms: 20,000 Calories per Dorm Room and Counting. American Journal of Preventive Medicine, 36, 523-526. http://dx.doi.org/10.1016/j.amepre.2009.01.030

[78] Hodson, K.T. (2012) The Impact of the Collegiate Athletic Dining Hall on the Well-Being of Student-Athletes. http://hdl.handle.net/2346/11534.

[79] Ding, D., Sallis, J.F., Norman, G.J., Saelens, B.E., Harris, S.K., Kerr, J., Rosenberg, D., Durant, N. and Glanz, K. (2012) Community Food Environment, Home Food Environment, and Fruit and Vegetable Intake of Children and Adolescents. Journal of Nutrition Education and Behavior, 44, 634-638. http://dx.doi.org/10.1016/j.jneb.2010.07.003

[80] Ingledew, D.K. and Markland, D. (2008) The Role of Motives in Exercise Participation. Psychology and Health, 23, 807-828. http://dx.doi.org/10.1080/08870440701405704

[81] Guerin, E., Fortier, M.S., O’Sullivan, T. and Neilson, C. (2012) Physical Activity Maintenance in Middle Aged Women: A Qualitative Ecological Study. Journal of Health Behavior and Public Health, 2, 1-13.

[82] Deci, E. and Ryan, R. (1985) Intrinsic Motivation and Self-Determination in Human Behavior. Plenum, New York. http://dx.doi.org/10.1007/978-1-4899-2271-7

[83] Deci, E. and Ryan, R. (2000) The "What" and "Why" of Goal Pursuits: Human Needs and the Self-Determination of Behavior. Psychological Inquiry, 11, 227-268. http://dx.doi.org/10.1207/S15327965PLI1104 01

[84] Deci, E. and Ryan, R. (2008) Self-Determination Theory: A Macrotheory of Human Motivation, Development, and Health. Canadian Psychology, 49, 182-185. http://dx.doi.org/10.1037/a0012801 